\title{
Imaging Alzheimer's disease pathophysiology with PET
}

\author{
Lucas Porcello Schilling ${ }^{1,2,3}$, Eduardo R. Zimmer ${ }^{1,2,3,4}$, Monica Shin ${ }^{1,2}$, \\ Antoine Leuzy ${ }^{1,2,5}$, Tharick A. Pascoal ${ }^{1,2}$, Andréa L. Benedet ${ }^{1,2}$, Wyllians Vendramini Borelli ${ }^{3}$, \\ André Palmini ${ }^{3}$, Serge Gauthier ${ }^{2}$, Pedro Rosa-Neto ${ }^{1,2}$
}

ABSTRACT. Alzheimer's disease (AD) has been reconceptualised as a dynamic pathophysiological process characterized by preclinical, mild cognitive impairment $(\mathrm{MCl})$, and dementia stages. Positron emission tomography (PET) associated with various molecular imaging agents reveals numerous aspects of dementia pathophysiology, such as brain amyloidosis, tau accumulation, neuroreceptor changes, metabolism abnormalities and neuroinflammation in dementia patients. In the context of a growing shift toward presymptomatic early diagnosis and disease-modifying interventions, PET molecular imaging agents provide an unprecedented means of quantifying the AD pathophysiological process, monitoring disease progression, ascertaining whether therapies engage their respective brain molecular targets, as well as quantifying pharmacological responses. In the present study, we highlight the most important contributions of PET in describing brain molecular abnormalities in AD.

Key words: Alzheimer's disease, positron emission tomography, amyloid imaging, neuroinflammation, neurodegeneration, tau.

\section{A FISIOPATOLOGIA DA DOENÇA DE ALZHEIMER ATRAVÉS DO PET}

RESUMO. A doença de Alzheimer tem sido reconceitualizada como um processo patofisiológico dinâmico caracterizado pelos estágios pré-clínico, comprometimento cognitivo leve e demência. A tomografia por emissão de pósitrons associada a vários agentes de imagem molecular revela numerosos aspectos da patofisiologia da demência tais como amiloidose cerebral, acúmulo de tau, mudanças em neurorreceptores, anormalidades de metabolismo e neuroinflamação nestes pacientes. No contexto de um crescimento em direção ao diagnóstico precoce pré-sintomático e intervenções modificadores da doença, a imagem de PET com agentes moleculares fornece meio para quantificar o processo patofisiológico da DA sem precedentes, monitorizar a progressão da doença, bem como quantificar resposta farmacológica. Aqui, nós realçamos as mais importantes contribuições do PET na descrição de anormalidades moleculares cerebrais na DA.

Palavras-chave: doença de Alzheimer, tomografia por emissão de positron, imagem amilóide, neuroinflamação, neurodegeneração, tau.

\section{INTRODUCTION}

A lzheimer's disease (AD) was first described Ain 1906, when the German psychiatrist Alois Alzheimer reported the clinical and pathological features from a patient called Auguste Deter. At age 51, she became afflicted by an obscure progressive neuropsychiatric condition characterized by severe cognitive decline associated with behavioral symptoms. Five years after admission, she became mute and confined to her bed. Similarly to many patients, her death came as a consequence of septicemia. At the necropsy, the brain histopathological examination revealed the presence of amyloid plaques and neurofibrillary tangles, both of which later became known

This study was conducted at the Douglas Mental Health Research Institute, Montreal, Canada.

${ }^{1}$ Translational Neuroimaging Laboratory (TNL), McGill Center for Studies in Aging (MCSA), Douglas Mental Health Research Institute, Montreal, Canada. ${ }^{2}$ Alzheimer's Disease Research Unit, MCSA, Douglas Mental Health Research Institute, Montreal, Canada. ${ }^{3}$ Brain Institute of Rio Grande do Sul, Pontifical Catholic

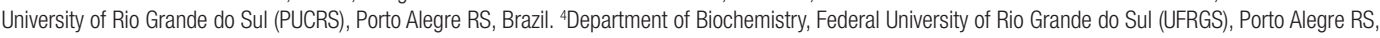
Brazil. ${ }^{5}$ Department NVS, Centre for Alzheimer Research, Division of Translational Alzheimer Neurobiology, Karolinska Institutet, Stockholm, Sweden.

Pedro Rosa-Neto. McGill Center for Studies in Aging, 6825 LaSalle Boulevad, Montreal, H4H 1R3 Quebec - Canada. E-mail: ac.lligcm@asor.ordep

Disclosure: The authors report no conflicts of interest.

Received December 10, 2015. Accepted in final form March 16, 2016. 
as the neuropathological hallmarks of $\mathrm{AD}$. The term "Alzheimer's disease" was introduced by the psychiatrist Emil Kraepelin in 1910, in his Handbook of Psychiatry.1,2 Initially considered a rare disease, AD became recognized as a frequent condition in aging individuals as well as the leading cause of dementia. ${ }^{3}$

The neuropathological features of $\mathrm{AD}$ constitute the extracellular deposition of amyloid- $\beta$ (A $\beta)$ aggregates (senile plaques), intracellular inclusions of hyperphosphorylated tau aggregates (neurofibrillary tangles; NFTs), brain atrophy and cell depletion. ${ }^{4}$ These features silently accumulate and propagate across brain regions for many years, leading to subsequent clinical and functional decline. At the stage of clinical symptoms of dementia, these pathophysiological processes have already significantly compromised a large proportion of brain circuits involved in cognition. In its typical presentation, $\mathrm{AD}$ is characterized by progressive cognitive impairment initially confined to the episodic memory system.

The research criteria for the diagnosis of $A D$ were first defined in 1984 by a working group jointly established by the National Institute of Neurological and Communicative Disorders and Stroke (NINCDS) and the Alzheimer's Disease and Related Disorders Association (ADRDA). ${ }^{5}$ The NINCDS-ADRDA criteria assumed a static association between the pathological and clinical characteristics of AD. ${ }^{6}$ These criteria were useful and widely adopted, remaining in use for over 25 years. During the last decade, important advances in genetics, biochemistry, clinical, and pathological characterization of dementias have taken place, including the development of in vivo biomarkers of $\mathrm{AD}$ pathophysiology, leading to changes in the criteria for $\mathrm{AD} .{ }^{6}$ An International Working Group (IWG) initiated these revisions, ${ }^{7,8}$ followed by the National Institute on Aging and Alzheimer's Association workgroup (NIA-AA), leading to new diagnostic criteria including predementia stages of $\mathrm{AD}$. In particular, the NIA-AA research criteria encompasses asymptomatic "preclinical" $\mathrm{AD},{ }^{9}$ mild cognitive impairment (MCI) due to $\mathrm{AD},{ }^{10}$ and $\mathrm{AD}$ dementia stages. ${ }^{11}$ This disease framework incorporates important advances such as the notion of clinical and pathophysiological progression, the genetic form of $\mathrm{AD}$, as well as atypical presentations of $\mathrm{AD}$. Importantly, $\mathrm{AD}$ pathophysiology now assumes a progressive cascade of events associated with $A \beta$ toxicity, which triggers a series of downstream biochemical cascades including tau hyperphosphorylation, synaptic depletion, ${ }^{12,13}$ neuroinflammation, ${ }^{14}$ and abnormal neurotransmission. ${ }^{15}$

Positron emission tomography (PET) is a noninvasive method capable of quantifying biological pro- cesses based on the dynamic distribution of radiotracers injected during the scanning session. There are numerous PET molecular imaging agents, each of which is specifically designed to quantify a single molecular target. They allow for the characterization of abnormal protein aggregation (fibrillary $\mathrm{A} \beta$ or hyperphosphorylated tau deposits), metabolic abnormalities (glucose metabolism and cerebral blood flow), and neuroinflammation (astrocytosis, microgliosis and phospholipase activity). This review article focuses on PET molecular imaging in $\mathrm{AD}$, reviewing the role of imaging biomarkers in the diagnosis and monitoring of key pathophysiological events of $A D$, which include $A \beta$ and tau deposition, neurodegeneration, and neuroinflammation.

\section{PET BIOMARKERS FOR AMYLOID DEPOSITION}

Though the pathogenesis of $\mathrm{AD}$ remains unclear, the hallmark of this neurodegenerative disease is the deposition of $A \beta$ plaques, together with other features, such as the presence of NFTs. A $\beta$ deposits are known to progressively accumulate in certain brain regions over the course of the disease, beginning long before the clinical onset. The canonical PET molecular agent capable of detecting fibrillary $\mathrm{A} \beta$ in vivo is the carbon- 11 labelled thioflavin T derivative 2-(4'-methylaminophenyl)-6hydroxybenzothiazole, also known as $\left[{ }^{11} \mathrm{C}\right]$ Pittsburgh Compound-B $\left.\left({ }^{11} \mathrm{C}\right] \mathrm{PiB}\right)$. The most widely studied amyloid PET tracer, $\left[{ }^{11} \mathrm{C}\right] \mathrm{PiB}$ is considered the benchmark for PET-amyloid imaging. ${ }^{16-18}$ The short half-life of carbon-11 (20 minutes), however, limits its use to centers possessing an on-site cyclotron and specialized radiochemistry. The new generation of amyloid ligands, labeled with fluorine-18, have a longer half-life of approximately 110 minutes. Due to these differences in half-life, these fluorine-18 labeled compounds can be regularly produced at a cyclotron site and distributed to other facilities (Table 1)..$^{19,20}$

Previous studies indicate that patients with MCI present $20-30 \%$ higher prevalence of amyloid positivity when compared to controls, which suggests that both amnestic and nonamnestic $\mathrm{MCI}$ are associated with an increased risk for $\mathrm{AD}$. This association is much more relevant in the amnestic MCI subtype, but it is important to highlight that a large number of MCI patients are amyloid negative, supporting the theory that $\mathrm{MCI}$ is not always due to amyloid-related $\mathrm{AD}$ pathology. ${ }^{21-25} \mathrm{~A}$ positive amyloid-PET scan increases the probability of conversion to $\mathrm{AD} ;{ }^{21,26,27}$ however, the interval over which $\mathrm{MCI}$ amyloid positive patients may convert to $\mathrm{AD}$ dementia is variable, ranging from 1 to 5 years. ${ }^{21,26}$ It is important to keep in mind the present limited clinical utility of detection of 
Table 1. Summary of amyloid imaging agents currently available for quantifying brain amyloid.

\begin{tabular}{|c|c|c|c|c|c|}
\hline & {$\left[{ }^{11} \mathrm{C}\right] \mathrm{PIB}$} & {$\left[{ }^{[8} \mathrm{F}\right.$ Flutemetamol } & {$\left[{ }^{18} \mathrm{~F}\right]$ Florbetapir } & {$\left[{ }^{[8} \mathrm{F}\right]$ Florbetaben } & {$\left[{ }^{18} \mathrm{~F}\right] \mathrm{NAV} 4694$} \\
\hline & Research Use & Vizamy $\left.\right|^{\circledR}$ & Amivid $^{\circledR}$ & Neuraceq $^{\circledR}$ & Phase 3 \\
\hline Alternative name & - & GE-067 & - & BAY-94-9172, AV-1 & {$\left[{ }^{18} \mathrm{~F}\right] A Z D 4694$} \\
\hline Parent molecule & Benzothiazole & Benzothiazole & Styrylpyridine & Stilbene & Benzothiazole \\
\hline Amyloid affinity (Ki, nM) & 0.9 & 0.7 & 2.2. & 2.4 & 0.7 \\
\hline Plasma metabolites & Polar & Polar & Polar and non-polar & Polar and non-polar & Polar \\
\hline Typical injected dose (MBq) & $250-450$ & $250-450$ & 300 & 300 & 300 \\
\hline Typical imaging time (min) & $40-90$ & $90-110$ & $50-70$ & $90-130$ & $50-60$ \\
\hline
\end{tabular}

$\mathrm{AD}$ pathophysiology in $\mathrm{MCI}$ patients, given the lack of efficacious therapy as well as the ethical limitations when proposing amyloid imaging in patients meeting clinical criteria for MCI. On the other hand, positive amyloidPET scans in $\mathrm{MCI}$ patients provides confirmation that this clinical situation occurs due to $\mathrm{AD}$ pathophysiology, supporting the idea of investing in non-pharmacological interventions, such as cognitive enrichment and diet and lifestyle changes. By contrast, a negative amyloidPET scan in patients presenting cognitive impairment suggests other non-AD pathologies, such as frontotemporal lobar degeneration, hippocampal sclerosis, or argyrophilic grain disease. Although Parkinson's disease (PD) and dementia with Lewy bodies (DLB) are neurodegenerative disorders associated with brain deposition of fibrillary aggregates of $\alpha$-synuclein protein, individuals with these synucleinopathies and cognitive decline have shown variability with regard to the presence of an abnormal amyloid-PET scan. ${ }^{28,29}$ Individuals presenting with Parkinson's disease (PD) dementia have shown lower brain amyloid burden than $\mathrm{AD}$, dementia with Lewy bodies, exhibiting similar burden to controls. On the other hand, patients presenting dementia with DLB have shown higher amyloid burden than controls, comparable to levels seen in $\mathrm{AD}$ patients. ${ }^{30,31}$ Interestingly, these studies have suggested that a positive amyloid-PET scan in DLB individuals might be associated with more rapid clinical progression. ${ }^{28,30}$

The clinical importance of amyloid imaging has been extensively debated. In order to delineate scenarios in which the use of amyloid PET radiotracers is appropriate in the evaluation of cognitive impairment, the Alzheimer's Association and the Society of Nuclear Medicine and Molecular Imaging have set up an Amyloid Imaging Taskforce (AIT) ${ }^{32}$ Performing a literature review in conjunction with expert opinion, the AIT defined a set of
Appropriate Use Criteria (AUC) for clinical amyloid imaging, recommending that the use of amyloid imaging be limited to patients showing progressive and unexplained cognitive decline with uncertain diagnosis, early onset dementia and/or atypical clinical presentation, and when knowledge of amyloid status is expected to alter the therapeutic approach. Clinical utilities of amyloid imaging are restricted to specific cases. Patients with early-onset dementia (commonly defined as onset before 65 years of age) have a lower probability of AD pathophysiology underlying their cognitive decline than late-onset cases. In this regard, amyloid imaging might clarify whether underlying brain amyloidosis is associated with clinical syndromes such as primary progressive aphasia, dementias characterized by a predominance of executive dysfunction, visuospatial symptoms, progressive apraxia, and corticobasal syndrome. Given the economic and family impact of the diagnosis of $\mathrm{AD}$ in this population, an elevated level of diagnostic certainty is highly desirable. Furthermore, the presence of amyloid pathology might provide the rationale for proposing the clinical use of cholinesterase inhibitors in this population. The AIT contraindicates the use of amyloid imaging in asymptomatic people or in those with a cognitive complaint but no clinical confirmation of impairment, for determining the severity of dementia and for non-medical reasons, such as insurance, legal or employment decisions.

Finally, recently incorporated into $\mathrm{AD}$ research diagnostic criteria, amyloid PET plays a major role in defining AD. The IWG criteria classified amyloid PET as a useful biomarker which supports clinical diagnosis, especially when the presentation is atypical. ${ }^{33}$ Hence, amyloid PET has increasingly been used in clinical trials, particularly for enriching study populations comprising individuals with a high probability of presenting AD or for monitoring target engagement of anti-amyloid therapies. How- 
ever, the clinical utility of amyloid PET has been increasingly discussed, particularly in the absence of effective disease modifying agents. ${ }^{32,34,35}$ The ensuing paragraphs summarize progress regarding amyloid imaging in $\mathrm{AD}$.

[ $\left.{ }^{11} \mathrm{C}\right]$ Pittsburgh Compound-B. $\left[{ }^{11} \mathrm{C}\right] \mathrm{PIB}$ exhibits a high affinity and specificity for $A \beta$ plaques, as opposed to Lewy bodies or tau proteins. ${ }^{36,37}$ showing high accuracy in the evaluation of $A \beta$ plaque burden. In individuals with $\left.\mathrm{AD},{ }^{[11} \mathrm{C}\right] \mathrm{PIB}$ uptake is distributed in the frontal, medial and lateral posterior parietal cortices, precuneus, occipital cortex and lateral temporal cortices, as well as in the striatum (Figure 1). ${ }^{16,38-40}$ Low $\left.{ }^{11} \mathrm{C}\right] \mathrm{PIB}$ uptake is typically observed in the cerebellar cortex.

A recent Cochrane review study on $\left[{ }^{11} \mathrm{C}\right] \mathrm{PIB}$ for early diagnosis of $\mathrm{AD}$ in individuals with $\mathrm{MCI}^{41}$ estimated sensitivity of $96 \%$ (95\% confidence interval: 87-99) and median specificity of 58\%. A growing consensus emerging from longitudinal studies indicates that diseasemodifying therapies targeting amyloid should be administered at very early stages of the disease. ${ }^{42}$ Concerted efforts worldwide are focusing on advancing the diagnosis of $\mathrm{AD}$ to a preclinical stage. ${ }^{43,44}$ Elevated $\left[{ }^{11} \mathrm{C}\right] \mathrm{PIB}$ binding in nondemented subjects indicates that it may be sensitive for the detection of preclinical $\mathrm{AD},{ }^{45}$ suggesting a 20 to 30-year interval between first amyloid positivity and onset of dementia. ${ }^{25}$

Presently, $\left[{ }^{11} \mathrm{C}\right] \mathrm{PIB}$ is one of the most accurate agents for localizing and quantifying $A \beta$ deposition; however, the short half-life of carbon- 11 restricts its use to facilities with an onsite cyclotron and expertise in carbon-11 radiochemistry. Hence, the overall production and utilization costs are not generally affordable. In order to solve this issue, recent studies haves focused on fluorine-18 labeled radiopharmaceuticals, whose longer half-life allows for regional distribution and commercialization. Widely used as a biomarker in the diagnostic criteria for $A D$, cerebrospinal fluid (CSF) also confirms $A \beta$ pathology, with $\operatorname{CSF} A \beta_{1-42}$ having an inverse correlation with $\left[{ }^{11} \mathrm{C}\right]$ PIB SUVR values. ${ }^{46}$ However, one limitation of CSF A $\beta_{1-42}$ is that it does not provide any regionalized information on amyloid burden in the brain.

Fluorine-18 labeled ligands. While the short half-life of carbon labeled radiotracers limits the application of $\left[{ }^{11} \mathrm{C}\right]$ PIB in clinical practice, fluorine-18 labeled amyloid PET radiopharmaceuticals have been developed, with a growing potential for clinical and research purposes. These compounds provide a new window of opportunity in the assessment of preclinical and clinical $\mathrm{AD}$ due to

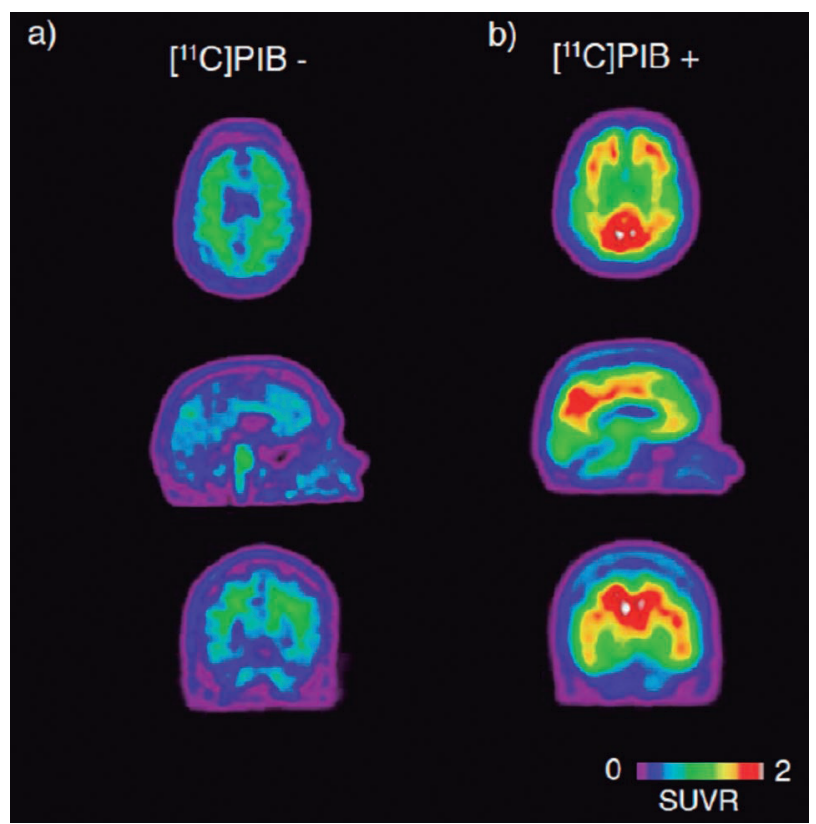

Figure 1. Amyloid signature. Representative $\left[{ }^{11} \mathrm{C}\right] \mathrm{PIB}$ PET images showing white matter uptake of $\left[{ }^{11} \mathrm{C}\right] \mathrm{PIB}$ in a patient with CBS (a; age 74 , MMSE 23), and extensive cortical uptake in a patient with AD (b; age 70, MMSE 28).

the 110-minute half-life of fluorine-18, a massive difference in terms of distribution logistics when compared to $\left[{ }^{11} \mathrm{C}\right] \mathrm{PIB}$ production. At present, four radiofluorinated labeled radiopharmaceuticals are drawing scientific attention: $\left[{ }^{18} \mathrm{~F}\right] 3-\mathrm{F}-\mathrm{PIB}\left(\left[{ }^{18} \mathrm{~F}\right]\right.$ flutemetamol) ${ }^{47}\left[{ }^{18} \mathrm{~F}\right]$ AV- 45 ([18 $\mathrm{F}]$ florbetapir) ${ }^{48}\left[{ }^{18} \mathrm{~F}\right] \mathrm{AV}-1$ or $\left[{ }^{18} \mathrm{~F}\right] \mathrm{BAY} 94-$ $9172\left(\left[{ }^{18} \mathrm{~F}\right]\right.$ florbetaben), ${ }^{49,50}$ and $\left[{ }^{18} \mathrm{~F}\right] \mathrm{AZD} 4694$ or $\left[{ }^{18} \mathrm{~F}\right]$ NAV4694. ${ }^{51}$

Similarly to $\left[{ }^{11} \mathrm{C}\right] \mathrm{PIB}$, these fluorine-18 amyloid tracers exhibit significant binding to fibrillar $A \beta$ in the brain, ${ }^{47,48}$ albeit with some differences. $\left.{ }^{18} \mathrm{~F}\right]$ Flutemetamol, $\left[{ }^{18} \mathrm{~F}\right]$ florbetapir, and $\left[{ }^{18} \mathrm{~F}\right]$ florbetaben are less specific than $\left[{ }^{11} \mathrm{C}\right] \mathrm{PIB}$, displaying white matter binding whereas $\left[{ }^{18} \mathrm{~F}\right] \mathrm{NAV} 4694$ shows more specific grey-white matter demarcation and better pharmacokinetic properties as a potential competitor of $\left[{ }^{11} \mathrm{C}\right]$ PIB PET. The Food and Drug Administration (FDA) and European Medicines Agency (EMA) have already approved $\left[{ }^{18} \mathrm{~F}\right]$ florbetapir $\left(\right.$ Amyvid $\left.\left.{ }^{\mathrm{TM}}\right),{ }^{18} \mathrm{~F}\right]$ flutemetamol (Vizamyl ${ }^{\mathrm{TM}}$ ), and $\left[{ }^{18} \mathrm{~F}\right]$ florbetaben (Neuraceq ${ }^{\mathrm{TM}}$ ) for use in clinical practice, while $\left[{ }^{18} \mathrm{~F}\right] \mathrm{NAV} 4694$ is currently in phase III trials. ${ }^{50,51}$

While holding great research potential, all four compounds discriminate healthy controls from $\mathrm{AD}$ subjects with high accuracy. $\left[{ }^{18} \mathrm{~F}\right]$ Florbetapir has shown remarkable accuracy in amyloid detection, with clinical application even in preclinical $\mathrm{AD} .^{52,53}$ The diagnostic value of $\left[{ }^{18} \mathrm{~F}\right]$ flutemetamol has been tested recently in symptom- 
atic and preclinical $\mathrm{AD}$, showing relevance in detecting primarily advanced stages of $A \beta$ deposition at both clinical and preclinical stages. ${ }^{54}\left[{ }^{18} \mathrm{~F}\right]$ Florbetaben is a highly accurate $A \beta$ PET tracer that has the potential to support the clinical diagnosis of $\mathrm{AD}$ and other causes of cognitive decline,${ }^{49}$ with similar visual and quantitative assessment in PET.

A third generation probe, $\left[{ }^{18} \mathrm{~F}\right] \mathrm{AZD} 4694$, called NAV4694, has been attracting growing attention for its near-identical imaging characteristics, but longer half-life to those of $\left.\left[{ }^{11} \mathrm{C}\right] \mathrm{PIB} .{ }^{18} \mathrm{~F}\right] \mathrm{NAV} 4694$ binds specifically to $A \beta$ plaques, with excellent frontal cortex-towhite matter ratios both in $\mathrm{AD}$ and healthy controls. ${ }^{51}$ The accuracy of $\left[{ }^{18} \mathrm{~F}\right] \mathrm{NAV} 4694$ in binding $\mathrm{A} \beta$ plaques has been tested, reliably discriminating $\mathrm{AD}$ patients from healthy controls, and satisfies requirements for clinical usage and evaluation of disease-modifying strategies in AD. ${ }^{55}$ In a recent study, $\left[{ }^{18} \mathrm{~F}\right] \mathrm{NAV} 4694$ exhibited a significant overlap in amyloid imaging with $\left[{ }^{11} \mathrm{C}\right] \mathrm{PIB}$ in patients with FTLD, theoretically an A $\beta$-free disease in most of its pathological subtypes. ${ }^{56}$ Also, the linear correlation of $\left[{ }^{18} \mathrm{~F}\right] \mathrm{NAV} 4694$ with $\left[{ }^{11} \mathrm{C}\right] \mathrm{PIB}$ of 0.95 is higher than the values reported for $\left[{ }^{18} \mathrm{~F}\right]$ florbetapir (range 0.33-0.64) and $\left[{ }^{18} \mathrm{~F}\right]$ florbetaben $(0.71) .{ }^{51}$

\section{PET BIOMARKERS FOR NEUROINFLAMMATION}

A factor known to be involved in the pathogenesis of $\mathrm{AD}$ is the immune response, with initial association between amyloid deposits and immune response emerging among elderly in their 70 s and 80 s. ${ }^{57,58}$ More recently, there is emerging knowledge on components of innate immunity associated with $\mathrm{AD}$ pathology, as well as increasing discussion over the beneficial and detrimental effects of the immune response in $\mathrm{AD}$. Another controversial topic is the start point of neuroinflammatory processes observed in $\mathrm{AD}$ brains, which raises the question as to whether inflammation is a cause or a consequence of $\mathrm{AD}$ pathology. Despite the initial assumption of their occurrence only in late stages of the disease, inflammatory changes in the CSF can be detected in MCI patients, revealing the possibility of involvement of the immune system at very early stages of $\mathrm{AD}^{59}$

In a bid to answer the as yet unsolved questions regarding the Janus face of inflammation in $\mathrm{AD}$, PET imaging is being used in vivo to trace markers of neuroinflammation with promising outcomes, as outlined below. ${ }^{60}$

Radiopharmaceuticals for imaging microglial activation. Neuroinflammatory changes are a part of AD pathology, and microglial activation in areas affected by neurodegeneration is a key brain tissue event. ${ }^{61}$ Microglial activation occurring in early stages of $\mathrm{AD}$ dementia is associated with a significant elevation in the fractional area of reactive microglia following the formation of neuritic plaques comprising fibrillar $A \beta .62-65$ Using a specific ligand for the $18-\mathrm{kDa}$ translocator protein (TSPO), formerly called the peripheral benzodiazepine receptor (PBR), $\left[{ }^{11} \mathrm{C}\right] \mathrm{PK} 11195$ quantification of microglial activation in vivo has been measured. ${ }^{66}$ Probably due to its poor specific binding, initial $\left.{ }^{11} \mathrm{C}\right] \mathrm{PK} 11195$ studies in AD showed negative results. ${ }^{67}$ However, improvements in the $\left[{ }^{11} \mathrm{C}\right] \mathrm{PK} 11195$ tracer, particularly with the utilization of its dextro-isomer, the radiotracer $\left[{ }^{11} \mathrm{C}\right]-(\mathrm{R})$ PK11195, revealed increased sensitivity for detecting TSPO expression in parieto-temporal, entorhinal, and cingulate cortices of $\mathrm{AD}$ patients. ${ }^{64}$ In $\left[{ }^{11} \mathrm{C}\right] \mathrm{PIB}+\mathrm{AD}$ patients, high microglial activation has been observed, with an inverse correlation between cognition and microglial activity ${ }^{68}$ However, a recent study reported that the inclusion of a vascular component results in an amplified signal in $\mathrm{AD}$ patients, ${ }^{69}$ suggesting that an increase in $\left[{ }^{11} \mathrm{C}\right]-(\mathrm{R})-\mathrm{PK} 11195$ sensitivity signal modeling may be required.

Other TSPO radiopharmaceuticals have been designed aimed at improving pharmacokinetics and specificity. In this regard, preclinical studies involving radiotracers $\left[{ }^{18} \mathrm{~F}\right] \mathrm{FEDAA} 1106$ or $\left[{ }^{11} \mathrm{C}\right] \mathrm{AC} 5216$ have shown promising results in $\mathrm{AD}$-like transgenic models, ${ }^{70,71}$ and $\left[{ }^{11} \mathrm{C}\right] \mathrm{DAA} 1106$ PET imaging showed greater binding in $\mathrm{AD}$ patients compared to healthy control subjects. ${ }^{72}$ Another recent clinical study using $\left[{ }^{18} \mathrm{~F}\right]$ FEDAA1106 - a novel TSPO ligand with in vitro affinity superior to that of $\left[{ }^{11} \mathrm{C}\right] \mathrm{DAA} 1106{ }^{73}$ - showed widespread increases in MCI patients when compared to healthy controls, with these values predicting the conversion to $\mathrm{AD}$ dementia stage within a 5-year follow-up period. ${ }^{74}$

Although applications in studies of $\mathrm{AD}$ patients have not been performed, $\left[{ }^{11} \mathrm{C}\right] \mathrm{AC} 5216$ has shown promising pharmacokinetic features and a higher affinity than $\left[{ }^{11} \mathrm{C}\right]$ PK11195 in healthy subjects. ${ }^{75}$ However, the potential clinical applications of TSPO radiotracers are limited by the rs6971 polymorphism in the TSPO gene, which confers lower uptake in polymorphism carriers $(\sim 30 \%)$ in comparison to non-carriers. ${ }^{76}$ Importantly, the cannabinoid receptor type 2 (CB2) was identified as a marker of microglial activation, ${ }^{77}$ leading to greater attention to the endocannabinoid system. In this respect, preclinical studies of CB2 using $\left[{ }^{11} \mathrm{C}\right] \mathrm{A}-836339$ showed upregulation in a transgenic model displaying cerebral amyloidosis. $^{78}$ 
Radiopharmaceuticals for imaging reactive astrocytosis. In $\mathrm{AD}$ post-mortem tissue, the augmented expression of glial fibrillary acidic (GFAP) and astroglial S100B proteins is typically observed, indicating an increase in the number of reactive astrocytes. ${ }^{79}$ Utilizing a ligand with a high affinity/specificity for monoamine oxidase $B$ (MAO-B), an enzyme expressed primarily on the mitochondrial membrane of reactive astrocytes, ${ }^{80,81}$ PET imaging using the carbon-11 labeled L-deprenyl $\left(\left[{ }^{11} \mathrm{C}\right]\right.$ DED) has revealed increased binding in patients with MCI, suggesting that astrocytosis is an early event in AD pathophysiology. ${ }^{82}$

\section{PET BIOMARKERS OF NEURODEGENERATION}

PET radiopharmaceuticals of tau pathology. Misfolding and aggregation of hyperphosphorylated tau deposition into NFTs has a key role in $\mathrm{AD}$ pathophysiology. ${ }^{83,84}$ It is has been proposed that tau pathology propagates across brain circuits. NFTs have been associated with neuronal dysfunction, cell death, and cognitive impairment. ${ }^{85}$ CSF levels of total tau ( $\mathrm{t}$-tau) and phosphorylated tau (p-tau) have been associated with disease severity, ${ }^{86}$ with altered tau levels in the CSF being interpreted as surrogate markers of neurodegeneration in $\mathrm{AD} .{ }^{87}$ Despite this evidence, the clinical application of CSF tau as an $\mathrm{AD}$ biomarker has been further discussed elsewhere. ${ }^{88}$

CSF tau biomarkers are somewhat disadvantageous compared to imaging biomarkers given the need for a lumbar puncture. Moreover, CSF measurements provide global estimates of the disease process without any information regarding the topographic localization of NFT. Finally, the quantification of p-tau and t-tau protein varies significantly across centres. ${ }^{89}$ Due to these features, imaging methods for NFT quantification are extremely important, particularly for assessing upcoming tau-based therapeutics. Given this scenario, several radiotracers characterized by high affinity for tau fibrils and with suitable kinetics have been developed, including the benzothiazole derivative $\left[{ }^{11} \mathrm{C}\right] \mathrm{PBB}$, the phenylquinoline derivatives- $\left[{ }^{18} \mathrm{~F}\right]$ THK-523, $\left[{ }^{18} \mathrm{~F}\right] \mathrm{THK}-5105$, and $\left[{ }^{18} \mathrm{~F}\right]$ THK-5117-and benzimidazole pyrimidine derivatives, such as $\left[{ }^{18} \mathrm{~F}\right] \mathrm{T} 807$ and $\left[{ }^{18} \mathrm{~F}\right] \mathrm{T} 808 .{ }^{90}$

$\left.{ }^{[11} \mathrm{C}\right] \mathrm{PBB} 3$ has shown to rapidly cross both the bloodbrain barrier (BBB) and neuronal plasma membranes, binding to intraneuronal tau inclusions. In vitro and ex vivo autoradiographic studies have shown that $\left[{ }^{11} \mathrm{C}\right] \mathrm{PBB} 3$ produced specific, high-contrast labeling of neuronal tau inclusions in the brain stem of mice models expressing human tau pathological mutations. The same findings were reported with in vitro autoradiography and $A D$ tissue, showing evident radiolabelling of fibrillar aggre- gates in specific regions of the hippocampus (including CA1), and the frontal cortex. Similarly, a clinical PET study using $\left[{ }^{11} \mathrm{C}\right] \mathrm{PBB} 3$ in probable $\mathrm{AD}$ patients revealed increased tracer binding in lateral temporal and frontal cortices, in line with the distribution of tau pathology at Braak stage V/VI, and with higher SUVRs correlating with lower memory scores. A slight increase in $\left[{ }^{11} \mathrm{C}\right] \mathrm{PBB} 3$ retention was also observed around the hippocampus of a control subject who showed decline on the Mini-Mental State Examination (MMSE), consistent with Braak stage III/IV or earlier. ${ }^{91}$

Aside from $\left[{ }^{11} \mathrm{C}\right] \mathrm{PBB} 3$, the fluorinated probes $\left[{ }^{18} \mathrm{~F}\right]$ T-807 and $\left[{ }^{18} \mathrm{~F}\right] \mathrm{T}-808$ are also potential tau ligands. An autoradiography study using AD brain tissue has shown that $\left[{ }^{18} \mathrm{~F}\right] \mathrm{T}-807$ exhibits strong binding to NFTs, with a selectivity estimate of 29-fold for tau relative to $A \beta{ }^{92}$ In addition, comparing double immunohistochemical staining of NFTs and $A \beta$ on adjacent tissue sections, $\left[{ }^{18} \mathrm{~F}\right] \mathrm{T}-807$ autoradiography showed that tracer binding co-localized with immunoreactive NFTs, not with $\mathrm{A} \beta$ plaques. ${ }^{93}$ In the case of $\left[{ }^{18} \mathrm{~F}\right] \mathrm{T}-808$, it also has a high affinity and good selectivity for NFTs over $A \beta$, which was indexed by autoradiographic studies. ${ }^{94}$ In addition, $\left[{ }^{18} \mathrm{~F}\right] \mathrm{T}-808$ presents fast brain uptake followed by a rapid washout, suggesting low non-specific binding, ${ }^{94}$ which is consistent with in vivo findings obtained using $\left[{ }^{18} \mathrm{~F}\right]$ T-807. ${ }^{93}$ Moreover, the first human brain using $\left[{ }^{18} \mathrm{~F}\right]$ T-807 showed elevated SUVR in AD compared to MCI and healthy control subjects. Distinct patterns of tracer accumulation, in line with Braak staging, was observed across the frontal, temporal and parietal cortices, as well as in the hippocampus/entorhinal region. ${ }^{92}$

Another class of fluorinated probes includes the THKs, which have exhibited high affinity and selectivity for tau aggregates. ${ }^{95}$ In vitro preliminary studies have reported $\left[{ }^{18} \mathrm{~F}\right] \mathrm{THK}-523$ binding affinity for tau fibrils, with subsequent autoradiographic analysis using $\mathrm{AD}$ medial temporal brain sections showing accumulation of $\left[{ }^{18} \mathrm{~F}\right] \mathrm{THK}-523$ in the pre- and pri- $\alpha$ layers of the entorhinal cortex and hippocampal CA1 region. Immunohistochemistry confirmed that these findings were consistent with the density of PHF-tau deposition..$^{96}$ Subsequently, histofluorescence and autoradiographic studies revealed that $\left[{ }^{18} \mathrm{~F}\right]$ THK-523 binding to NFTs co-localized with tau immunoreactivity, with no visible binding to $A \beta$ plaques. ${ }^{97}$ However, recent immunohistochemical and histofluorescence studies questioned $\left.{ }^{18} \mathrm{~F}\right] \mathrm{THK}-523$ 's future in both research and clinical settings due to very high non-specific white matter binding. ${ }^{98}$ Moreover, preliminary clinical data have suggested that $\left[{ }^{18} \mathrm{~F}\right] \mathrm{THK}-523$ does not bind tau inclusions in non-AD tauopathies. ${ }^{99}$ 
The second generation of THKs was developed, which includes $\left[{ }^{18} \mathrm{~F}\right]$ THK-5105 and $\left[{ }^{18} \mathrm{~F}\right]$ THK-5117. Binding studies conducted in vitro using $\left[{ }^{18} \mathrm{~F}\right] \mathrm{THK}-5105$ and $\left[{ }^{18} \mathrm{~F}\right]$ THK-5117 have found increased binding affinity to synthetic truncated tau (K18 $\Delta$ K280) fibrils-comprising the four repeat regions (244-372) in the absence of lysine $280(\triangle \mathrm{K} 280)$ - with both tracers proving superior to $\left[{ }^{18} \mathrm{~F}\right] \mathrm{THK}-523$. The selective binding capacity of these compounds was further examined using in vitro autoradiography and $\mathrm{AD}$ mesial temporal brain sections, showing increased accumulation of the radiotracer with particularly high binding in the Sommer's sector of the hippocampus, the parahippocampus, and the subiculum. These findings were confirmed through staining and immunohistochemistry, with reduced binding among healthy controls. ${ }^{100}$ Additional assessment of $\left[{ }^{18} \mathrm{~F}\right] \mathrm{THK}-$ 5105, conducted using $\left[{ }^{11} \mathrm{C}\right] \mathrm{PIB}$ and $\mathrm{AD}$ hemibrain sections, observed dense accumulation of $\left[{ }^{18} \mathrm{~F}\right] \mathrm{THK}-5105$ in tau-rich areas-including the hippocampus/parahippocampus, insula, cingulate gyrus and inferior and middle temporal gyri - with the pattern of tracer binding corresponding to the recognized distribution of tau pathology but not to that of $A \beta$ or areas showing elevated retention of $\left[{ }^{11} \mathrm{C}\right] \mathrm{PIB}$. In addition, further studies of biodistribution conducted in normal mice showed profuse and rapid brain uptake and fast clearance, with the kinetics of both tracers superior to those reported for $\left[{ }^{18} \mathrm{~F}\right]$ THK-523. ${ }^{100-102}$

$\left[{ }^{18} \mathrm{~F}\right] \mathrm{FDG}$ Radiotracer. The glucose analogue 2-deoxy-2$\left({ }^{18} \mathrm{~F}\right)$ fluoro-D-glucose $\left(\left[{ }^{18} \mathrm{~F}\right] \mathrm{FDG}\right) \mathrm{PET}$ has been utilized to assess cerebral glucose metabolism. $\left.{ }^{[18} \mathrm{F}\right] \mathrm{FDG}$ images have been interpreted as markers of neuronal activity ${ }^{103}$ and synaptic density. ${ }^{104}$ The typical AD metabolic signature consists of hypometabolism in the parietotemporal association, medial temporal, posterior cingulate and frontal cortices, with relative preservation of the visual cortex, primary sensory motor cortices, basal ganglia, thalamus, and cerebellum (Figure 2). ${ }^{105-109}$ This hypometabolic signature is frequently observed in $A D$ patients and in over $85 \%$ of pathologically-confirmed cases. ${ }^{106}$ However, in atypical focal cortical syndromes of $\mathrm{AD}$, topographic variants of hypometabolism have been identified. For example, compared to typical AD, patients with logopenic primary progressive aphasia presented with disproportionate left temporoparietal hypometabolism. ${ }^{110}$ Patients with posterior cortical atrophy showed hypometabolism predominantly in occipito-parietal regions; some patients can present hypometabolism in the frontal eye fields. ${ }^{111}$ Patients with early onset $\mathrm{AD}$ also show greater metabolic reduc-

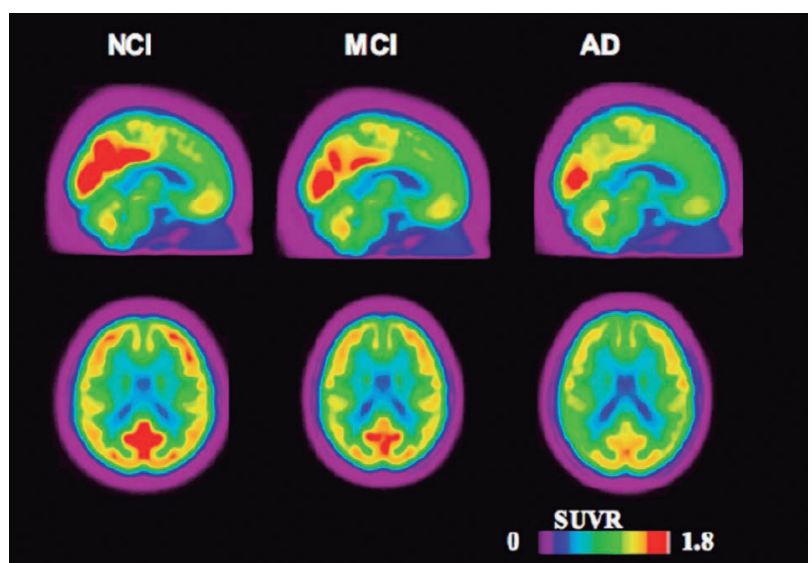

Figure 2. Representative PET $\left[{ }^{18} \mathrm{~F}\right.$ FDG images acquired from a total of 103 individuals with normal cognition ( $\mathrm{NCl}, \mathrm{N}=17)$, mild cognitive impairment $(\mathrm{MCl}, \mathrm{N}=52)$ and dementia due to $A D(A D, N=27)$ obtained from a total of 103 structural MRI and $\left[{ }^{18} \mathrm{~F}\right] \mathrm{FDG}$ scans from the Alzheimer's Disease Neuroimage Initiative (ADNI) database. The hot color scale represents the magnitude of $\left[{ }^{18} \mathrm{~F}\right] \mathrm{FDG}$ standardized uptake value ratio (SUVR), proportional to glucose uptake. Note lower $\left[{ }^{18} \mathrm{~F}\right] \mathrm{FDG}$ SUVRs in $\mathrm{MCl}$ and $\mathrm{AD}$ as compared to controls. High SUVRs are particularly reduced in the posterior cingulate, precuneus and prefrontal (medial and dorsolateral) cortices. Imaging Methods: MRI images were corrected for non-linearity, classified (white, grey matter and CSF) and automatically segmented into cortical regions. Standard uptake value ratio (SUVR) images were calculated in PET native space using the cerebellum as a reference image. Images were subsequently resampled into the standard stereotaxic space and averaged using minctools.

tions, with hypometabolism from mild dementia comparable to that observed in late onset cases with severe dementia. ${ }^{112}$ These findings are supported by studies showing more aggressive progression from patients with early onset $\mathrm{AD}^{113}$ and, possibly, by the cognitive reserve theory. ${ }^{114}$

In amnestic MCI (aMCI) patients, the pattern of hypometabolic changes usually occurs in brain regions classically affected in $\mathrm{AD},{ }^{115}$ but to a lesser degree. ${ }^{116-118}$ The patterns of brain metabolism in aMCI and nonamnestic MCI (naMCI) subjects are similar, however, aMCI has shown a decrease in medial temporal lobe metabolism and naMCI hypometabolism in the right prefrontal region. ${ }^{119,120}$ Some authors report that the anterior hippocampal formation can contribute to differentiating MCI patients from healthy control subjects, although other data refutes this, with the partial volume effect in the metabolism of the hippocampal formation on $\left[{ }^{18} \mathrm{~F}\right] \mathrm{FDG}$ imaging constituting a complicating factor. ${ }^{121-125}$ The posterior cingulate is the most relevant area for predicting conversion from $\mathrm{MCI}$ to $\mathrm{AD}$, given that hippocampal hypometabolism is highly influenced by the atrophy observed on MRI and, after correcting 
for the partial volume effect, this finding is no longer supported. ${ }^{117}\left[{ }^{18} \mathrm{~F}\right] \mathrm{FDG}$ has limited clinical value in MCI patients due to the lack of specificity for $\mathrm{AD}$ pathophysiology. At a population level, however, subjects with MCI presenting a more marked or 'AD-like' pattern have been found to convert to dementia at higher rates, ${ }^{126,127}$ with accuracies in the range of 75 to $100 \% .{ }^{128,129}$ The magnitude of hypometabolism in the parietal and posterior cingulate cortices in $\mathrm{MCI}$ is associated with memory decline. ${ }^{130,131}$ As compared to decliners, stable MCI populations tend to exhibit hypometabolism restricted to the dorsolateral frontal cortex. ${ }^{132,133}$

In order to study the progression to $\mathrm{MCI}$ and $\mathrm{AD}$ among cognitively normal older individuals, $\left[{ }^{18} \mathrm{~F}\right] \mathrm{FDG}$ PET has been used to predict cognitive decline with an accuracy approaching $80 \% .{ }^{121,123}$ Progressive reductions in PET glucose metabolism were observed years before the appearance of clinical symptoms, with reductions in the hippocampus preceding declines in cortical regions ${ }^{134}$ in a clinicopathological study that evaluated cognitively normal individuals followed through $\mathrm{MCI}$ to pathologically-confirmed $\mathrm{AD}$. The same metabolic changes have been noted in cognitively normal subjects homozygous for a susceptibility gene, the apolipoprotein E (APOE) $\varepsilon 4$ allele, ${ }^{130,135}$ asymptomatic carriers of genetic mutations associated with early onset familial $\mathrm{AD},{ }^{128,129,136}$ and those with a maternal family history of $\mathrm{AD}$, as compared to those with a paternal history or no family history of AD. ${ }^{137}$ Ultimately, $\left[{ }^{18} \mathrm{~F}\right] \mathrm{FDG}$ will potentially prove of use in the characterization of a subgroup of patients exhibiting neurodegeneration in the absence of $A \beta$ deposition. ${ }^{138,139}$ These patients, classified in the category of "suspected non-amyloid pathophysiology (SNAP)", could suggest that the onset of neurodegeneration in $\mathrm{AD}$ may not depend on the accumulation of $A \beta .{ }^{140}$

\section{IMAGING ALZHEIMER'S DISEASE PATHOPHYSIOLOGY IN EXPERIMENTAL MODELS}

A miniaturized version of PET, termed microPET, has made non-invasive imaging of small animals possible, such as rats and mice. In addition, advances in genetic engineering have led to the development of diverse animal models harboring human pathological gene mutations, which are capable of mimicking amyloid and tau pathologies (for review see (141)). These models show progressive deposition of amyloid or tau, in parallel with significant cognitive decline, and are highly suited to longitudinal assessment with microPET.

To date, several studies have investigated $\mathrm{AD}$ pathophysiological events in rodent models with microPET (for review see (142)). However, few such studies have been conducted using a longitudinal design. Recently, the first prolonged longitudinal study with microPET evaluating amyloid was published and revealed nonlinear patterns of amyloid deposition during full disease progression. ${ }^{143}$ By contrast, to our knowledge, there are no longitudinal studies in the literature following tau pathology, and such studies are anxiously awaited by the $\mathrm{AD}$ community. ${ }^{144}$ In this context, longitudinal studies associating these animal models and microPET imaging have high translational capability, which indicates that data collected can be rapidly translated to clinical studies. In addition, microPET longitudinal studies offer unprecedented opportunities for monitoring the effectiveness of innovative therapeutic strategies.

\section{CONCLUSION}

Predictions based on biomarkers indicate that $\mathrm{AD}$ pathophysiological abnormalities precede the onset of clinical symptoms by at least two decades. By obtaining earlier $\mathrm{AD}$ diagnosis, it will be possible to develop potential innovative therapies that may impact the natural progression of $\mathrm{AD}$. In fact, several clinical studies testing potential new drugs are currently underway with amyloid and tau being the most promising pharmacological targets (for review see (145)). In this scenario, PET radiotracers and neuropathological features for these processes are crucial to determine amyloid and tau engagement and to assess treatment response in clinical trials. In keeping with this, radiopharmaceuticals for neuroinflammatory molecular imaging can equally contribute to the development of potentially effective anti-inflammatory interventions. Although the majority of $\mathrm{PET}$ studies in $\mathrm{AD}$ populations have focused on $A \beta$ imaging, several 'non-amyloid' radiopharmaceuticals exist for evaluating neurodegeneration, neuroinflammation and perturbations in neurotransmission across the spectrum of $\mathrm{AD}$, potentially contributing to improved therapeutic perspectives for $\mathrm{AD}$ (for review see (146)).

At present, neurology is experiencing a new era which encompasses imaging assessment for patients suspected of having AD. Thus, it is extremely important to accurately establish those patients who are candidates for performing a cerebral PET exam (e.g. amyloid imaging). In the case of amyloid positivity, this biomarker-based information reflects an elevated risk for $\mathrm{AD}$, and health professionals should exercise caution when ordering this test in non-demented patients (e.g. healthy subjects and MCI patients). In the coming few years, when more effective therapies are likely to become available, amyloid imaging will be increasingly applied to identify 
Table 2. PET imaging signatures in Alzheimer's disease.

\begin{tabular}{|c|c|c|c|}
\hline Biological target & Radiotracers & Findings & Typical brain regions involved \\
\hline Amyloid deposition & $\begin{array}{l}{\left[{ }^{11} \mathrm{C}\right] \mathrm{PIB}} \\
{\left[{ }^{18} \mathrm{~F} \text { Florbetapir }\right.} \\
{\left[{ }^{18} \mathrm{~F} \text { Florbetaben }\right.} \\
{\left[{ }^{18} \mathrm{~F} \text { Flutemetamol }\right.} \\
{\left[{ }^{18} \mathrm{~F} \text { NAV4694 }\right.}\end{array}$ & Increased retention & $\begin{array}{l}\text { Frontal cortex, medial and lateral posterior parietal cortices, precuneus } \\
\text { Occipital cortex, lateral, temporal cortices and striatum }\end{array}$ \\
\hline Tau pathology & $\begin{array}{l}{\left[{ }^{18} \mathrm{~F}\right] \text { T807 }} \\
{\left[{ }^{18} \mathrm{~F}\right] \text { T808 }} \\
{\left[{ }^{18} \mathrm{~F}\right] \text { THK523 }} \\
{\left[{ }^{18} \mathrm{~F}\right] \text { THK5105 }} \\
{\left[{ }^{18} \mathrm{~F}\right] \text { THK5117 }} \\
{\left[{ }^{11} \mathrm{C}\right] \text { PBB3 }}\end{array}$ & Increased retention & $\begin{array}{l}\text { Frontal cortex, temporal cortex, parietal cortex and hippocampus/ } \\
\text { entorhinal region }\end{array}$ \\
\hline Glucose metabolism & {$\left[{ }^{18} \mathrm{~F}\right] \mathrm{FDG}$} & Low uptake & $\begin{array}{l}\text { Parietotemporal association cortices, medial temporal cortex, posterior } \\
\text { cingulate and frontal cortex (at later stages) }\end{array}$ \\
\hline Neuroinflammation & $\begin{array}{l}{\left[{ }^{11} \mathrm{C}\right] \mathrm{PK} 11195} \\
{\left[{ }^{11} \mathrm{C}\right] \mathrm{DAA} 1106} \\
{\left[{ }^{18} \mathrm{~F}\right] \mathrm{FEDAA} 1106} \\
{\left[{ }^{11} \mathrm{C}\right] \mathrm{AC} 5216} \\
{\left[{ }^{11} \mathrm{C}\right] \mathrm{A} 836339} \\
{\left[{ }^{11} \mathrm{C}\right] \mathrm{L}-\text { deprenyl }}\end{array}$ & Increased retention & Widespread retention within the whole brain \\
\hline
\end{tabular}

patients with early $\mathrm{AD}$ or at risk of developing $\mathrm{AD}$; preferably in association with $\left[{ }^{18} \mathrm{~F}\right] \mathrm{FDG}$ imaging in order to combine pathological (amyloid deposition) and metabolic (hypometabolism) information. Other radiotracers will also play a key role for research in $\mathrm{AD}$ (Table 2), especially in targeting novel therapies and for monitoring the response and efficacy of new drugs (e.g. tau and neuroinflammation).

Author contribution. Lucas Porcello Schilling collected and critically analysed literature, contributed with tables and wrote the paper; Eduardo R. Zimmer collected and critically analysed literature, contributed with figures and wrote the paper; Monica Shin collected and critically analysed literature and wrote the paper. Antoine Leuzy collected and critically analysed literature, contributed with figures and wrote the paper; Tharick A. Pascoal collected and critically analysed literature and wrote the paper; Andréa L. Benedet collected and critically analysed literature and wrote the paper. Wyllians V. Borelli collected and critically analysed literature and wrote the paper. André Palmini collected and critically analysed literature and wrote the paper; Serge Gauthier collected and critically analysed literature and wrote the paper; Pedro Rosa Neto collected and critically analysed literature and wrote and reviewed the paper.

\section{REFERENCES}

1. Cipriani G, Dolciotti C, Picchi L, Bonuccelli U. Alzheimer and his disease: a brief history. Neurol Sci. 2011;32(2):275-9.

2. Dahm R. Alzheimer's discovery. Curr Biol. 2006;16(21):R906-10.

3. Brookmeyer R, Johnson E, Ziegler-Graham K, Arrighi HM. Forecasting the global burden of Alzheimer's disease. Alzheimers Dement. 2007; 3(3):186-91.

4. Duyckaerts C, Delatour B, Potier MC. Classification and basic pathology of Alzheimer disease. Acta Neuropathol. 2009;118(1):5-36.

5. McKhann G, Drachman D, Folstein M, Katzman R, Price D, Stadlan EM. Clinical diagnosis of Alzheimer's disease: report of the NINCDSADRDA Work Group under the auspices of Department of Health and Human Services Task Force on Alzheimer's Disease. Neurology. 1984;34(7):939-44.

6. Jack CR, Jr., Albert MS, Knopman DS, et al. Introduction to the recommendations from the National Institute on Aging-Alzheimer's Association workgroups on diagnostic guidelines for Alzheimer's disease. Alzheimers Dement. 2011;7(3):257-62.
7. Dubois B, Feldman $\mathrm{HH}$, Jacova $\mathrm{C}$, et al. Research criteria for the diagnosis of Alzheimer's disease: revising the NINCDS-ADRDA criteria Lancet Neurol. 2007;6(8):734-46.

8. Dubois B, Feldman $\mathrm{HH}$, Jacova $\mathrm{C}$, et al. Revising the definition of Alzheimer's disease: a new lexicon. Lancet Neurol. 2010;9(11):1118-27.

9. Sperling RA, Aisen PS, Beckett LA, et al. Toward defining the preclinical stages of Alzheimer's disease: recommendations from the National Institute on Aging-Alzheimer's Association workgroups on diagnostic guidelines for Alzheimer's disease. Alzheimers Dement 2011;7(3):280-92.

10. Albert MS, DeKosky ST, Dickson D, et al. The diagnosis of mild cognitive impairment due to Alzheimer's disease: recommendations from the National Institute on Aging-Alzheimer's Association workgroups on diagnostic guidelines for Alzheimer's disease. Alzheimers Dement 2011;7(3):270-9.

11. McKhann GM, Knopman DS, Chertkow $\mathrm{H}$, et al. The diagnosis of dementia due to Alzheimer's disease: recommendations from the National Institute on Aging-Alzheimer's Association workgroups on 
diagnostic guidelines for Alzheimer's disease. Alzheimers Dement 2011;7(3):263-9.

12. Jack CR, Jr., Knopman DS, Jagust WJ, et al. Hypothetical model of dynamic biomarkers of the Alzheimer's pathological cascade. Lancet Neurol. 2010;9(1):119-28.

13. Jack CR, Jr., Knopman DS, Jagust WJ, et al. Tracking pathophysiological processes in Alzheimer's disease: an updated hypothetical model of dynamic biomarkers. Lancet Neurol. 2013;12(2):207-16.

14. McGeer PL, McGeer EG. The amyloid cascade-inflammatory hypothesis of Alzheimer disease: implications for therapy. Acta Neuropathol. 2013;126(4):479-97.

15. Govoni S, Mura E, Preda S, et al. Dangerous Liaisons between Beta-Amyloid and Cholinergic Neurotransmission. Curr Pharm Des. 2014;20(15):2525-38.

16. Klunk WE, Engler $\mathrm{H}$, Nordberg $A$, et al. Imaging brain amyloid in Alzheimer's disease with Pittsburgh Compound-B. Ann Neurol 2004;55(3):306-19.

17. Kemppainen NM, Aalto S, Wilson IA, et al. PET amyloid ligand [11C] PIB uptake is increased in mild cognitive impairment. Neurology. 2007; 68(19):1603-6.

18. Ikonomovic MD, Klunk WE, Abrahamson EE, et al. Post-mortem correlates of in vivo PiB-PET amyloid imaging in a typical case of Alzheimer's disease. Brain. 2008;131(Pt 6):1630-45.

19. Leuzy A, Zimmer ER, Heurling K, Rosa-Neto P, Gauthier S. Use of amyloid PET across the spectrum of Alzheimer's disease: clinical utility and associated ethical issues. Amyloid. 2014;21(3):143-8.

20. Leuzy A, Zimmer ER, Bhat V, Rosa-Neto P, Gauthier S. Imaging biomarkers for amyloid: a new generation of probes and what lies ahead. Int Psychogeriatr. 2014;26(5):703-7.

21. Okello A, Koivunen J, Edison P, et al. Conversion of amyloid positive and negative $\mathrm{MCl}$ to $\mathrm{AD}$ over 3 years: an 11C-PIB PET study. Neurology. 2009;73(10):754-60.

22. Pike KE, Savage G, Villemagne VL, et al. Beta-amyloid imaging and memory in non-demented individuals: evidence for preclinical Alzheimer's disease. Brain. 2007;130(Pt 11):2837-44.

23. Vandenberghe $\mathrm{R}$, Van Laere $\mathrm{K}$, Ivanoiu A, et al. 18F-flutemetamol amyloid imaging in Alzheimer disease and mild cognitive impairment: a phase 2 trial. Ann Neurol. 2010;68(3):319-29.

24. Wolk DA, Price JC, Saxton JA, et al. Amyloid imaging in mild cognitive impairment subtypes. Ann Neurol. 2009;65(5):557-68.

25. Jansen WJ, Ossenkoppele R, Knol DL, et al. Prevalence of cerebral amyloid pathology in persons without dementia: a meta-analysis. JAMA. 2015;313(19):1924-38.

26. Nordberg A, Carter SF, Rinne J, et al. A European multicentre PET study of fibrillar amyloid in Alzheimer's disease. Eur J Nucl Med Mol Imaging. 2013;40(1):104-14.

27. Forsberg $A$, Engler $H$, Almkvist $O$, et al. PET imaging of amyloid deposition in patients with mild cognitive impairment. Neurol Aging. 2008;29(10):1456-65.

28. Gomperts SN, Rentz DM, Moran E, et al. Imaging amyloid deposition in Lewy body diseases. Neurology. 2008;71(12):903-10.

29. Petrou M, Dwamena BA, Foerster BR, et al. Amyloid deposition in Parkinson's disease and cognitive impairment: a systematic review. Mov Disord. 2015;30(7):928-35.

30. Edison P, Rowe CC, Rinne JO, et al. Amyloid load in Parkinson's disease dementia and Lewy body dementia measured with [11C] PIB positron emission tomography. J Neurol Neurosurg Psychiatry. 2008;79(12):1331-8.

31. Claassen DO, Lowe VJ, Peller PJ, Petersen RC, Josephs KA. Amyloid and glucose imaging in dementia with Lewy bodies and multiple systems atrophy. Parkinsonism Relat Disord. 2011;17(3):160-5.

32. Johnson KA, Minoshima S, Bohnen NI, et al. Appropriate use criteria for amyloid PET: a report of the Amyloid Imaging Task Force, the Society of Nuclear Medicine and Molecular Imaging, and the Alzheimer's Association. J Nuclear Med. 2013;54(3):476-90.

33. Dubois $\mathrm{B}$, Feldman $\mathrm{HH}$, Jacova $\mathrm{C}$, et al. Advancing research diagnostic criteria for Alzheimer's disease: the IWG-2 criteria. Lancet Neurol. 2014;13(6):614-29.

34. Soucy JP, Bartha R, Bocti C, et al. Clinical applications of neuroimaging in patients with Alzheimer's disease: a review from the Fourth Canadian Consensus Conference on the Diagnosis and Treatment of Dementia 2012. Alzheimers Res Ther. 2013;5(Suppl 1):S3.
35. Rowe CC, Villemagne VL. Amyloid imaging with PET in early Alzheimer disease diagnosis. Med Clin North Am. 2013;97(3):377-98.

36. Fodero-Tavoletti MT, Smith DP, McLean CA, et al. In vitro characterization of Pittsburgh compound-B binding to Lewy bodies. J Neurosci. 2007;27(39):10365-71.

37. Lockhart A, Lamb JR, Osredkar T, et al. PIB is a non-specific imaging marker of amyloid-beta (Abeta) peptide-related cerebral amyloidosis. Brain. 2007;130(Pt 10):2607-15.

38. Buckner RL, Snyder AZ, Shannon BJ, et al. Molecular, structural, and functional characterization of Alzheimer's disease: evidence for a relationship between default activity, amyloid, and memory. J Neurosci. 2005;25(34):7709-17.

39. Braak H, Braak E. Alzheimer's disease: striatal amyloid deposits and neurofibrillary changes. J Neuropathol Exp Neurol. 1990;49(3):215-24.

40. Brilliant MJ, Elble RJ, Ghobrial M, Struble RG. The distribution of amyloid beta protein deposition in the corpus striatum of patients with Alzheimer's disease. Neuropathol Appl Neurobiol. 1997;23(4):322-5.

41. Zhang S, Smailagic N, Hyde C, et al. (11)C-PIB-PET for the early diagnosis of Alzheimer's disease dementia and other dementias in people with mild cognitive impairment (MCl). Cochrane 2014;7:CD010386.

42. Sperling RA, Jack CR, Jr., Aisen PS. Testing the right target and right drug at the right stage. Sci Transl Med. 2011;3(111):111cm33.

43. Pascoal TA, Mathotaarachchi S, Mohades S, et al. Amyloid-beta and hyperphosphorylated tau synergy drives metabolic decline in preclinical Alzheimer's disease. Mol Psychiatry. 2016. doi: 10.1038/mp.2016.37.

44. Benedet $A L$, Labbe $A$, Lemay $P$, et al. Epistasis analysis links immune cascades and cerebral amyloidosis. J Neuroinflammation. 2015;12:227.

45. Mintun MA, Larossa GN, Sheline YI, et al. [11C]PIB in a nondemented population: potential antecedent marker of Alzheimer disease. Neurology. 2006;67(3):446-52.

46. Toledo JB, Bjerke M, Da X, et al. Nonlinear Association Between Cerebrospinal Fluid and Florbetapir F-18 beta-Amyloid Measures Across the Spectrum of Alzheimer Disease. JAMA Neurology. 2015;72(5):571-81.

47. Wolk DA, Grachev ID, Buckley C, et al. Association between in vivo fluorine 18-labeled flutemetamol amyloid positron emission tomography imaging and in vivo cerebral cortical histopathology. Arch Neurol. 2011;68(11):1398-403.

48. Clark CM, Schneider JA, Bedell BJ, et al. Use of florbetapir-PET for imaging beta-amyloid pathology. JAMA. 2011;305(3):275-83.

49. Syed YY, Deeks E. [(18)F]Florbetaben: A Review in beta-Amyloid PET Imaging in Cognitive Impairment. CNS Drugs. 2015;29(7):605-13.

50. Sabri O, Sabbagh MN, Seibyl J, et al. Florbetaben PET imaging to detect amyloid beta plaques in Alzheimer's disease: Phase 3 study. Alzheimers Dement. 2015;11(8):964-74.

51. Rowe CC, Pejoska S, Mulligan RS, et al. Head-to-head comparison of 11C-PiB and 18F-AZD4694 (NAV4694) for beta-amyloid imaging in aging and dementia. J Nuclear Med. 2013;54(6):880-6.

52. Fischer FU, Wolf D, Scheurich A, Fellgiebel A, Alzheimer's Disease Neuroimaging I. Altered whole-brain white matter networks in preclinical Alzheimer's disease. Neuroimage Clin. 2015;8:660-6.

53. Rosenberg PB, Wong DF, Edell SL, et al. Cognition and amyloid load in Alzheimer disease imaged with florbetapir F 18(AV-45) positron emission tomography. Am J Geriatr Psychiatry. 2013;21(3):272-8.

54. Thal DR, Beach TG, Zanette M, et al. [(18)F]flutemetamol amyloid positron emission tomography in preclinical and symptomatic Alzheimer's disease: Specific detection of advanced phases of amyloid-beta pathology. Alzheimers Dement. 2015;11(8):975-85.

55. Cselenyi Z, Jonhagen ME, Forsberg A, et al. Clinical validation of 18F-AZD4694, an amyloid-beta-specific PET radioligand. J Nuclear Med. 2012;53(3):415-24.

56. Rowe CC, Villemagne VL. Brain amyloid imaging. J Nuclear Med Technol. 2013;41(1):11-8.

57. Ishii T, Haga S. Immuno-electron microscopic localization of immunoglobulins in amyloid fibrils of senile plaques. Acta Neuropathol. 1976;36(3):243-9.

58. Eikelenboom P, Stam FC. Immunoglobulins and Complement Factors in Senile Plaques - an Immunoperoxidase Study. Acta Neuropathol.1982;57(2-3):239-42.

59. Brosseron F, Krauthausen M, Kummer M, Heneka MT. Body fluid cytokine levels in mild cognitive impairment and Alzheimer's disease: a comparative overview. Mol Neurobiol. 2014;50(2):534-44.

60. Zimmer ER, Leuzy A, Benedet AL, Breitner J, Gauthier S, Rosa-Neto P. 
Tracking neuroinflammation in Alzheimer's disease: the role of positron emission tomography imaging. J Neuroinflammation. 2014;11:120.

61. McGeer EG, McGeer PL. Inflammatory processes in Alzheimer's disease. Prog Neuropsychopharmacol Biol Psychiatry. 2003;27(5):741-9.

62. Vehmas AK, Kawas CH, Stewart WF, Troncoso JC. Immune reactive cells in senile plaques and cognitive decline in Alzheimer's disease. Neurol Aging. 2003;24(2):321-31.

63. Akiyama $\mathrm{H}$, Barger $\mathrm{S}$, Barnum S, et al. Inflammation and Alzheimer's disease. Neurol Aging. 2000;21(3):383-421.

64. Cagnin A, Brooks DJ, Kennedy AM, et al. In-vivo measurement of activated microglia in dementia. Lancet. 2001;358(9280):461-7.

65. Versijpt JJ, Dumont F, Van Laere KJ, K, et al. Assessment of neuroinflammation and microglial activation in Alzheimer's disease with radiolabelled PK11195 and single photon emission computed tomography. A pilot study. Eur Neurol. 2003;50(1):39-47.

66. Papadopoulos V, Baraldi M, Guilarte TR, et al. Translocator protein (18kDa): new nomenclature for the peripheral-type benzodiazepine receptor based on its structure and molecular function. Trends Pharmacol Sci. 2006;27(8):402-9.

67. Groom GN, Junck L, Foster NL, Frey KA, Kuhl DE. PET of peripheral benzodiazepine binding sites in the microgliosis of Alzheimer's disease. J Nuclear Med. 1995;36(12):2207-10.

68. Edison P, Archer HA, Gerhard A, et al. Microglia, amyloid, and cognition in Alzheimer's disease: An [11C](R)PK11195-PET and [11C]PIB-PET study. Neurobiol Dis. 2008;32(3):412-9.

69. Tomasi G, Edison P, Bertoldo A, et al. Novel reference region model reveals increased microglial and reduced vascular binding of 11C-(R)PK11195 in patients with Alzheimer's disease. J Nuclear Med. 2008;49(8):1249-56.

70. Higuchi M. Visualization of brain amyloid and microglial activation in mouse models of Alzheimer's disease. Curr Alzheimer Res. 2009; 6(2): $137-43$

71. Maeda J, Zhang MR, Okauchi T, et al. In vivo positron emission tomographic imaging of glial responses to amyloid-beta and tau pathologies in mouse models of Alzheimer's disease and related disorders. J Neurosci. 2011;31(12):4720-30.

72. Yasuno F, Ota M, Kosaka J, et al. Increased binding of peripheral benzodiazepine receptor in Alzheimer's disease measured by positron emission tomography with [11C]DAA1106. Biol Psychiatry. 2008;64(10):835-41.

73. Wischik CM, Edwards PC, Lai RY, Roth M, Harrington CR. Selective inhibition of Alzheimer disease-like tau aggregation by phenothiazines. Proc Natl Acad Sci U S A. 1996;93(20):11213-8.

74. Yasuno F, Kosaka J, Ota M, et al. Increased binding of peripheral benzodiazepine receptor in mild cognitive impairment-dementia converters measured by positron emission tomography with [(1)(1)C]DAA1106. Psychiatry Res. 2012;203(1):67-74

75. Miyoshi M, Ito H, Arakawa R, et al. Quantitative analysis of peripheral benzodiazepine receptor in the human brain using PET with (11)C-AC5216. J Nuclear Med. 2009;50(7):1095-101.

76. Yoder KK, Nho K, Risacher SL, Kim S, Shen L, Saykin AJ. Influence of TSPO genotype on 11C-PBR28 standardized uptake values. J Nuclear Med. 2013;54(8):1320-2

77. Horti AG, Gao Y, Ravert HT, et al. Synthesis and biodistribution of [11C] A-836339, a new potential radioligand for PET imaging of cannabinoid type 2 receptors (CB2). Bioorg Med Chem. 2010;18(14):5202-7.

78. Benito C, Tolon RM, Pazos MR, Nunez E, Castillo Al, Romero J. Cannabinoid CB2 receptors in human brain inflammation. $\mathrm{Br} \mathrm{J}$ Pharmacol. 2008;153(2):277-85

79. Verkhratsky A, Olabarria M, Noristani HN, Yeh CY, Rodriguez JJ. Astrocytes in Alzheimer's disease. Neurotherapeutics. 2010;7(4):399-412.

80. Fowler JS, MacGregor RR, Wolf AP, et al. Mapping human brain monoamine oxidase $A$ and $B$ with 11C-labeled suicide inactivators and PET. Science. 1987;235(4787):481-5.

81. Fowler JS, Volkow ND, Wang GJ, et al. Age-related increases in brain monoamine oxidase B in living healthy human subjects. Neurol Aging. 1997;18(4):431-5.

82. Carter SF, Scholl M, Almkvist O, et al. Evidence for astrocytosis in prodromal Alzheimer disease provided by 11C-deuterium-L-deprenyl: a multitracer PET paradigm combining 11C-Pittsburgh compound B and 18F-FDG. J Nuclear Med. 2012;53(1):37-46.

83. Jucker M, Walker LC. Pathogenic protein seeding in Alzheimer disease and other neurodegenerative disorders. Ann Neurol. 2011;70(4):532-40.
84. Spires-Jones TL, Stoothoff WH, de Calignon A, Jones PB, Hyman BT. Tau pathophysiology in neurodegeneration: a tangled issue. Trends Neurosci. 2009;32(3):150-9.

85. Iqbal K, Liu F, Gong CX, Alonso Adel C, Grundke-lqbal I. Mechanisms of tau-induced neurodegeneration. Acta Neuropathol.2009;118(1):53-69.

86. de Calignon A, Polydoro M, Suarez-Calvet M, et al. Propagation of tau pathology in a model of early Alzheimer's disease. Neuron. 2012;73(4): 685-97.

87. Buerger K, Teipel SJ, Zinkowski R, et al. CSF tau protein phosphorylated at threonine 231 correlates with cognitive decline in $\mathrm{MCl}$ subjects. Neurology. 2002;59(4):627-9.

88. Augustinack JC, Schneider A, Mandelkow EM, Hyman BT. Specific tau phosphorylation sites correlate with severity of neuronal cytopathology in Alzheimer's disease. Acta Neuropathol. 2002;103(1):26-35.

89. Blennow K, Hampel H. CSF markers for incipient Alzheimer's disease. Lancet Neurol. 2003:2(10):605-13.

90. Zimmer ER, Leuzy A, Gauthier S, Rosa-Neto P. Developments in Tau PET Imaging. Can J Neurol Sci. 2014;41(5):547-53.

91. Maruyama M, Shimada H, Suhara T, et al. Imaging of tau pathology in a tauopathy mouse model and in Alzheimer patients compared to normal controls. Neuron. 2013;79(6):1094-108.

92. Chien DT, Bahri S, Szardenings AK, et al. Early clinical PET imaging results with the novel PHF-tau radioligand [F-18]-T807. J Alzheimers Dis. 2013;34(2):457-68.

93. Xia CF, Arteaga J, Chen G, et al. [(18)F]T807, a novel tau positron emission tomography imaging agent for Alzheimer's disease. Alzheimers Dement. 2013;9(6):666-76.

94. Zhang W, Arteaga J, Cashion DK, et al. A highly selective and specific PET tracer for imaging of tau pathologies. J Alzheimers Dis. 2012;31(3): $601-12$.

95. Okamura N, Suemoto T, Furumoto S, et al. Quinoline and benzimidazole derivatives: candidate probes for in vivo imaging of tau pathology in Alzheimer's disease. J Neurosci. 2005;25(47):10857-62.

96. Harada R, Okamura N, Furumoto $\mathrm{S}$, et al. Comparison of the binding characteristics of [18F]THK-523 and other amyloid imaging tracers to Alzheimer's disease pathology. Eur J Nucl Med Mol Imaging. 2013;40(1):125-32

97. Fodero-Tavoletti MT, Okamura N, Furumoto S, et al. 18F-THK523: a novel in vivo tau imaging ligand for Alzheimer's disease. Brain. 2011; 134(Pt 4):1089-100.

98. Villemagne VL, Furumoto S, Fodero-Tavoletti MT, et al. In vivo evaluation of a novel tau imaging tracer for Alzheimer's disease. Eur J Nucl Med Mol Imaging. 2014;41(5):816-26.

99. Fodero-Tavoletti MT, Furumoto S, et al. Assessing THK523 selectivity for tau deposits in Alzheimer's disease and non Alzheimer's disease tauopathies. Alzheimers Res Ther. 2014;6(1):11.

100. Okamura N, Furumoto S, Harada R, et al. Novel 18F-Labeled Arylquinoline Derivatives for Noninvasive Imaging of Tau Pathology in Alzheimer Disease. J Nuclear Med. 2013;54(8):1420-7.

101. Johnson KA, Schultz A, Betensky RA, et al. Tau PET imaging in aging and early Alzheimer's disease. Ann Neurol. Ann Neurol. 2016;79(1): 110-9.

102. Marquie M, Normandin MD, Vanderburg CR, et al. Validating novel tau positron emission tomography tracer [F-18]-AV-1451 (T807) on postmortem brain tissue. Ann Neurol. 2015;78(5):787-800.

103. Sokoloff L, Reivich M, Kennedy C, et al. The [14C]deoxyglucose method for the measurement of local cerebral glucose utilization: theory, procedure, and normal values in the conscious and anesthetized albino rat. J Neurochem. 1977;28(5):897-916.

104. Rocher AB, Chapon F. Blaizot X, Baron JC, Chavoix C. Resting-state brain glucose utilization as measured by PET is directly related to regional synaptophysin levels: a study in baboons. Neuroimage. 2003; 20(3):1894-8

105. Silverman DH, Small GW, Phelps ME. Clinical Value of Neuroimaging in the Diagnosis of Dementia. Sensitivity and Specificity of Regional Cerebral Metabolic and Other Parameters for Early Identification of Alzheimer's Disease. Clinical positron imaging : official journal of the Institute for Clinical PET. 1999;2(3):119-30.

106. Silverman DH, Small GW, Chang CY, et al. Positron emission tomography in evaluation of dementia: Regional brain metabolism and longterm outcome. JAMA2001;286(17):2120-7.

107. Mosconi L. Brain glucose metabolism in the early and specific diagnosis 
of Alzheimer's disease. FDG-PET studies in MCl and AD. Eur J Nucl Med Mol Imaging. 2005;32(4):486-510.

108. Minoshima S, Giordani B, Berent S, Frey KA, Foster NL, Kuhl DE. Metabolic reduction in the posterior cingulate cortex in very early Alzheimer's disease. Ann Neurol. 1997;42(1):85-94.

109. Scholl M, Damian A, Engler H. Fluorodeoxyglucose PET in Neurology and Psychiatry. PET Clin. 2014;9(4):371-90.

110. Rabinovici GD, Jagust WJ, Furst AJ, et al. Abeta amyloid and glucose metabolism in three variants of primary progressive aphasia. Ann Neurol. 2008;64(4):388-401.

111. Nestor PJ, Caine D, Fryer TD, Clarke J, Hodges JR. The topography of metabolic deficits in posterior cortical atrophy (the visual variant of Alzheimer's disease) with FDG-PET. J Neurol Neurosurg Psychiatry. 2003;74(11):1521-9.

112. Kim EJ, Cho SS, Jeong Y, et al. Glucose metabolism in early onset versus late onset Alzheimer's disease: an SPM analysis of 120 patients. Brain 2005;128(Pt 8):1790-801.

113. Jacobs D, Sano M, Marder K, et al. Age at onset of Alzheimer's disease: relation to pattern of cognitive dysfunction and rate of decline. Neurology. 1994;44(7):1215-20.

114. Katzman R, Brown T, Thal LJ, et al. Comparison of rate of annual change of mental status score in four independent studies of patients with Alzheimer's disease. Ann Neurol. 1988;24(3):384-9.

115. Mosconi L, Brys M, Glodzik-Sobanska L, De Santi S, Rusinek H, de Leon MJ. Early detection of Alzheimer's disease using neuroimaging. Exp Gerontol. 2007;42(1-2):129-38.

116. Nestor PJ, Fryer TD, Smielewski P, Hodges JR. Limbic hypometabolism in Alzheimer's disease and mild cognitive impairment. Ann Neurol. 2003;54(3):343-51.

117. De Santi S, de Leon MJ, Rusinek H, et al. Hippocampal formation glucose metabolism and volume losses in $\mathrm{MCl}$ and $\mathrm{AD}$. Neurobiol Aging. 2001;22(4):529-39.

118. Mosconi L, De Santi S, Li Y, et al. Visual rating of medial temporal lobe metabolism in mild cognitive impairment and Alzheimer's disease using FDG-PET. Eur J Nucl Med Mol Imaging. 2006;33(2):210-21.

119. Clerici F, Del Sole A, Chiti A, et al. Differences in hippocampal metabolism between amnestic and non-amnestic $\mathrm{MCl}$ subjects: automated FDG-PET image analysis. The quarterly journal of nuclear medicine and molecular imaging : official publication of the Italian Assoc Nucl Med. 2009;53(6):646-57.

120. Coutinho AM, Porto FH, Duran FL, et al. Brain metabolism and cerebrospinal fluid biomarkers profile of non-amnestic mild cognitive impairment in comparison to amnestic mild cognitive impairment and normal older subjects. Alzheimers Res Ther. 2015;7(1):58.

121. Mosconi L, De Santi S, Li J, et al. Hippocampal hypometabolism predicts cognitive decline from normal aging. Neurobiol Aging. 2008;29(5): 676-92.

122. Mosconi L, Tsui WH, De Santi S, et al. Reduced hippocampal metabolism in $\mathrm{MCl}$ and $\mathrm{AD}$ : automated FDG-PET image analysis. Neurology. 2005;64(11):1860-7.

123. de Leon MJ, Convit A, Wolf OT, et al. Prediction of cognitive decline in normal elderly subjects with 2-[(18)Ffluoro-2-deoxy-D-glucose/ poitron-emission tomography (FDG/PET). Proc Natl Acad Sci U S A. 2001;98(19):10966-71.

124. Samuraki M, Matsunari I, Chen WP, et al. Partial volume effect-corrected FDG PET and grey matter volume loss in patients with mild Alzheimer's disease. Eur J Nucl Med Mol Imag. 2007;34(10):1658-69.

125. Chetelat G, Desgranges B, Landeau B, et al. Direct voxel-based compar ison between grey matter hypometabolism and atrophy in Alzheimer's disease. Brain 2008;131(Pt 1):60-71.

126. Chetelat G, Desgranges $B$, de la Sayette V, Viader F, Eustache $F$, Baron JC. Mild cognitive impairment: Can FDG-PET predict who is to rapidly convert to Alzheimer's disease? Neurology. 2003;60(8): 1374-7.

127. Mosconi L, Perani D, Sorbi S, et al. MCl conversion to dementia and the APOE genotype: a prediction study with FDG-PET. Neurology. 2004; 63(12):2332-40.

128. Drzezga A, Lautenschlager N, Siebner $\mathrm{H}$, et al. Cerebral metabolic changes accompanying conversion of mild cognitive impairment into Alzheimer's disease: a PET follow-up study. Eur J Nucl Med Mol Imag. 2003;30(8):1104-13.

129. Herholz K, Nordberg A, Salmon E, et al. Impairment of neocortical metabolism predicts progression in Alzheimer's disease. Dement Geriatr Cogn Disord. 1999;10(6):494-504.

130. Anchisi D, Borroni B, Franceschi M, et al. Heterogeneity of brain glucose metabolism in mild cognitive impairment and clinical progression to Alzheimer disease. Arch Neurol. 2005;62(11):1728-33.

131. Herholz K, Salmon E, Perani D, et al. Discrimination between Alzheimer dementia and controls by automated analysis of multicenter FDG PET. Neuroimage. 2002;17(1):302-16

132. Rossi S, Cappa SF, Babiloni C, et al. Prefrontal [correction of Prefontal] cortex in long-term memory: an "interference" approach using magnetic stimulation. Nat Neurosci. 2001;4(9):948-52.

133. Desgranges B, Baron JC, Eustache F. The functional neuroanatomy of episodic memory: the role of the frontal lobes, the hippocampal formation, and other areas. Neuroimage. 1998;8(2):198-213.

134. Mosconi L, Mistur R, Switalski R, et al. FDG-PET changes in brain glucose metabolism from normal cognition to pathologically verified Alzheimer's disease. Eur J Nucl Med Mol Imag. 2009;36(5):811-22.

135. Drzezga A, Grimmer T, Riemenschneider M, et al. Prediction of individual clinical outcome in $\mathrm{MCl}$ by means of genetic assessment and (18)F-FDG PET. J Nucl Med. 2005;46(10):1625-32.

136. Bateman RJ, Xiong C, Benzinger TL, et al. Clinical and biomarker changes in dominantly inherited Alzheimer's disease. New Engl J Med. 2012;367(9):795-804.

137. Mosconi L, Brys M, Switalski R, et al. Maternal family history of Alzheimer's disease predisposes to reduced brain glucose metabolism. Proc Natl Acad Sci U S A.2007:104(48):19067-72.

138. Jack CR, Jr., Knopman DS, Weigand SD, et al. An operational approach to National Institute on Aging-Alzheimer's Association criteria for preclinical Alzheimer disease. Ann Neurol. 2012;71(6):765-75.

139. Knopman DS, Jack CR, Jr., Wiste HJ, et al. Short-term clinical outcomes for stages of NIA-AA preclinical Alzheimer disease. Neurology. 2012; 78(20):1576-82.

140. Knopman DS, Jack CR, Jr., Wiste HJ, et al. Brain injury biomarkers are not dependent on beta-amyloid in normal elderly. Ann Neurol. 2013;73(4):472-80.

141. Gotz J, Ittner LM. Animal models of Alzheimer's disease and frontotemporal dementia. Nat Rev Neurosci. 2008;9(7):532-44.

142. Zimmer ER, Parent MJ, Cuello AC, Gauthier S, Rosa-Neto P. MicroPET imaging and transgenic models: a blueprint for Alzheimer's disease clinical research. Trends Neurosci. 2014;37(11):629-41.

143. Maier FC, Wehrl HF, Schmid AM, et al. Longitudinal PET-MRI reveals beta-amyloid deposition and rCBF dynamics and connects vascular amyloidosis to quantitative loss of perfusion. Nat Med. 2014;20(12): 1485-92.

144. Zimmer ER, Leuzy A, Bhat V, Gauthier S, Rosa-Neto P. In vivo tracking of tau pathology using positron emission tomography (PET) molecular imaging in small animals. Transl Neurodegener. 2014;3(1):6.

145. Qian X, Hamad B, Dias-Lalcaca G. The Alzheimer disease market. Nat Rev Drug Discov. 2015;14(10):675-6.

146. Schilling LPL A, Zimmer ER, Gauthier S, Rosa-Neto P. Nonamyloid PET biomarkers and Alzheimer' $s$ disease : current and future perspectives. Future Neurol. 2014;9(6):597-613. 